\title{
AMS DATING ON THE SHELL BAR SECTION FROM QAIDAM BASIN, NE TIBETAN PLATEAU, CHINA
}

\section{H C Zhang ${ }^{1} \bullet$ H F Fan • F Q Chang • W X Zhang • G L Lei • M S Yang • Y B Lei • L Q Yang}

Key Laboratory of Western China's Environmental Systems, MOE; College of Earth Sciences and Environments, Lanzhou University, Lanzhou 730000, China. Also: State Key Laboratory of Lake Science and Environment, Nanjing Institute of Geography and Limnology, Chinese Academy of Sciences (CAS), Nanjing 210008, China.

\begin{abstract}
Radiocarbon dating by accelerator mass spectrometry (AMS) of the shell bar section of Qaidam Basin, NE Tibetan Plateau, shows that this section was formed between $\sim 39.7$ and $\sim 17.5{ }^{14} \mathrm{C}$ kyr $\mathrm{BP}$ and represented the highest paleolake development period since the Late Pleistocene. It was difficult to obtain reliable dates due to the low organic carbon content, which was formed mainly by authochtonous algae-bacteria (Zhang et al. 2007a). In order to improve the dating, ${ }^{14} \mathrm{C}$ ages of both the alkali residual and acid-soluble components of the organic carbon were measured to check the consistency of the dating results. Total organic carbon (TOC) content and stable carbon isotopes $\left(\delta^{13} \mathrm{C}_{\mathrm{org}}\right)$ might also be used as critical references for checking the reliability of dates. For example, in our study of the shell bar section from Qaidam Basin, we found that when the TOC content was higher than $0.15 \%$ and/or $\delta^{13} \mathrm{C}_{\mathrm{org}}$ was lower than $-23 \%$, the AMS dates were reliable. AMS dating of fossil shells demonstrated that they could provide valuable age information. The ages given by fossil shells are comparable to those of bulk carbonate from a similar sampling site, and are about 15 18 kyr older than the ages given by organic matter. Due to the U/Th dating requirements and open nature of the system, we concluded that U/Th dating results are unreliable and that this technique is unsuitable for dating halite deposits from Qaidam Basin.
\end{abstract}

\section{INTRODUCTION}

As the largest high-elevation inland basin on the Tibetan Plateau, Qaidam Basin has been the focus of attention of studies on sedimentology, tectonics, mineraology, hydrology, climatology, biology (mainly microfossils), and archaeology since the late 1950s (e.g. Sun 1974, 1990; Chen et al. 1987a,b; Chen and Bowler 1985, 1986; Bowler et al. 1986; Huang et al. 1987; Zhang 1988; Jiang and Yang 2001). Numerous dates on core samples-obtained by conventional ${ }^{14} \mathrm{C},{ }^{230} \mathrm{Th}$, and paleomagnetic studies - showed that the lake deposits of the Late Pleistocene could extend to $210 \mathrm{~m}$ depth (Derbyshire et al. 1985; Wang et al. 1986; Zhang and Zhang 1991; Huang et al. 1995; Liu et al. 1998). Dating suggested that the salt layer in the upper 40-60 m was deposited in the last $24 \mathrm{kyr}$ (Zhang 1975; Chen et al. 1987a,b; Huang and Cai 1987; Liang and Huang 1995) and could be attributed to lake-water evaporation induced by climate change and by the shrinking of the Qarhan paleolake (Chen and Bowler 1985; Yang et al. 1995; Jiang and Yang 2001).

Geological investigations and drillings revealed that under the salt layer there are 35- to 60-m-thick continuous lake deposits, which were dated to about 25-40 kyr BP (Chen and Bowler 1985). These deposits have been attributed to the formation of a high paleolake level during humid, warm climatic conditions, while Qarhan was occupied by a huge mesohaline-freshwater paleolake (Chen et al. 1987a,b). Unfortunately, a comprehensive survey of the dates shows a confused picture not only because the dates from one core vary from those of another, but also there are frequent and massive reversals existing within the same core. In addition, the $\mathrm{NaCl}$ mineral crystals were dated extensively using ${ }^{230} \mathrm{Th}$ methods, and the bottom of the salt layers were extrapolated to $\sim 50 \mathrm{kyr} \mathrm{BP}$ (Huang and Cai 1987; Liang and Huang 1995), which means that lake deposits under these salt layers should be older than $50 \mathrm{kyr} \mathrm{BP}$. Consequently, all the ${ }^{14} \mathrm{C}$ dates on the underlying lacustrine deposits may be incorrect if the ${ }^{230} \mathrm{Th}$ dates are considered reliable.

${ }^{1}$ Corresponding author. Email: zhanghc@niglas.ac.cn. 
In light of these contradictions, it would seem difficult to accurately reconstruct the paleolake evolutionary history and paleoclimatic changes. Further studies are needed to clarify these problems, and the present paper is a first step to reaching such a goal.

\section{STUDY AREA}

Qaidam Basin has an average elevation of $2800 \mathrm{~m}$ asl and covers an area of $1.2 \times 10^{5} \mathrm{~km}^{2}$, making it the largest high-elevation inland basin on the NE Tibetan Plateau $\left(35^{\circ} 40^{\prime}-39^{\circ} 20^{\prime} \mathrm{N}, 90^{\circ} 00^{\prime}-\right.$ $99^{\circ} 20^{\prime} \mathrm{E}$ ). The basin is surrounded by the Kunlun Mountains to the south, Altun Mountains to the west, and Qilian Mountains to the north, with peaks of these mountains rising to $4500-5000 \mathrm{~m}$ asl.

Qaidam Basin has a hyperarid continental climate and is considered one of the most arid areas of the world. The annual mean precipitation is only $20 \sim 40 \mathrm{~mm}$, while the annual average potential evaporation is $3250 \mathrm{~mm}, 100$ times the annual precipitation. The annual average temperature is $\sim 2{ }^{\circ} \mathrm{C}$ with a January mean of about -10 to $-15{ }^{\circ} \mathrm{C}$ and a low temperature extreme of $-30^{\circ} \mathrm{C}$. In July, temperatures rise to a mean of $15 \sim 17{ }^{\circ} \mathrm{C}$ with a high temperature extreme of $30^{\circ} \mathrm{C}$, indicating a unique seasonal variation.

Several salt lakes exist in the basin, the largest being the Qarhan salt lake. This lake, which is the subject of this paper, stretches $168 \mathrm{~km}$ from west to east and ranges from $20-40 \mathrm{~km}$ from south to north, covering an area of $\sim 6000 \mathrm{~km}^{2}$. The elevation at the lowest part of Qarhan salt lake is $2675 \mathrm{~m}$ asl. This low-level area contains sedimentation and has had a subsiding center since the Quaternary era (about the last 2.5 Myr). The subsiding center combined with an uplifting of the plateau results in the thickness of the Quaternary age deposition reaching 2000-3000 m (Liu et al. 1998).

\section{SAMPLING SITE}

The shell bar is thus named because it is composed of fossil shells (Corbicula) in the shape of a bar. It is located at the southeastern end of the Qarhan paleolake $\left(36^{\circ} 30^{\prime} \mathrm{N}, 96^{\circ} 12^{\prime} \mathrm{E}\right)$ in Qaidam Basin, NW China. It is 2-3 m higher than the surrounding playa surface (Figure 1, left) and stretches in a NWW-SEE direction for $2130 \mathrm{~m}$, the widest part being $140 \mathrm{~m}$ with a mean elevation of $\sim 2700 \mathrm{~m}$ asl (varying between 2698-2702 $\mathrm{m}$ asl). It is the highest site at which we have found fossil shells of Corbicula from the Late Pleistocene.

The section studied was a manually excavated profile $2.6 \mathrm{~m}$ thick, not including the 10 -cm-thick overlying salt crystal $(\mathrm{NaCl})$ layer (Figure 1, middle). According to sedimentation structures, grain size, and color, the section could be divided into 2 parts with 9 layers. The upper part of the section was $112 \mathrm{~cm}$ thick and comprised mainly fine-sand and sand with undisturbed fossil shells. This part could be further divided into layer $1(0-55 \mathrm{~cm})$ and layer $2(55-112 \mathrm{~cm})$. The lower section was $148 \mathrm{~cm}$ thick and had silt-clay and clay textures. In this part, there were 3 layers of sediments with abundant original, undisturbed fossil shells, which were found at depths of 112-127, 142-149, and $185-210 \mathrm{~cm}$. Figure 2 shows that the bottom layer (layer 9) was composed of yellowish fine-sand, which was hard and physically different from the upper layers. A total of 90 samples (including 1 salt sample) were taken continuously from top to bottom at $3-5 \mathrm{~cm}$ intervals, according to the sediment properties. All samples were mixed well in the laboratory and divided into different parts for analyses. The samples were handled properly to prevent contamination.

\section{METHODS}

Accelerator mass spectrometry (AMS) ${ }^{14} \mathrm{C}$ dating was used to investigate the reliability and accuracy of the results. Ages of various components (e.g. acid residual and humic acids of the organic 


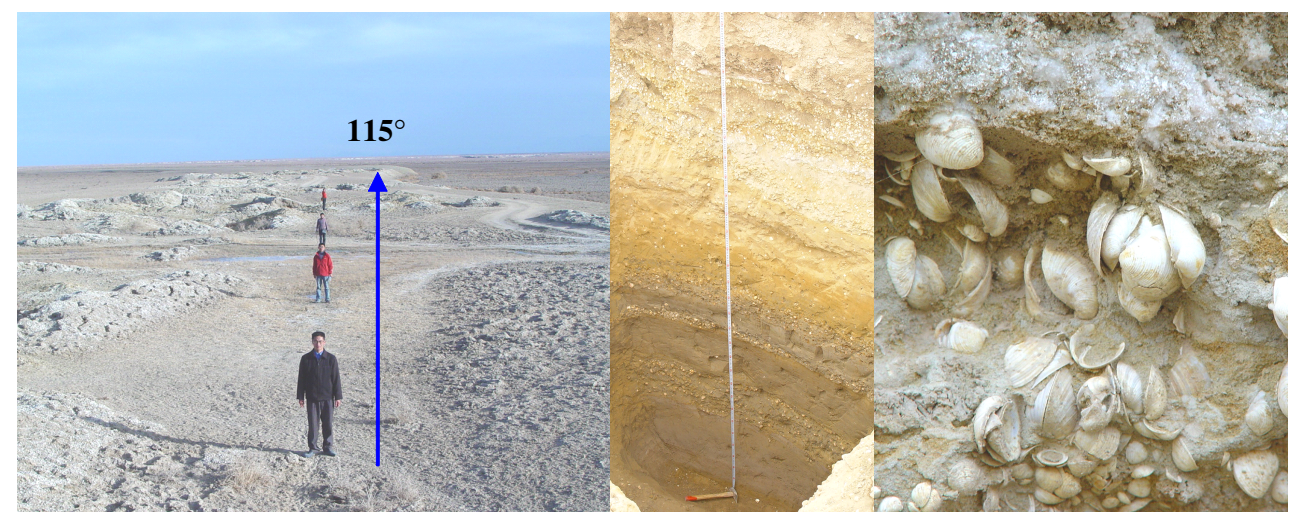

Figure 1 The shell bar (left), the section studied (middle), and fossil shells at the upper part of the section and overlying salt crystals (right). The distribution pattern of the shells that struggled for survival just under the salt layer implies a sudden salinity increase of lake water and an abrupt climate-environmental change in the area. The surface of the shell bar was disturbed by local people digging for shells in the past. (It has been under preservation since the 1990s.)

matter) from the same sample were determined. Age differences of a variety of materials (e.g. organic matter and fossil shells in the same test sample) and age differences at the same sampling position were evaluated. AMS dates were determined at the Leibniz Laboratory for Radiometric Dating and Stable Isotope Research at Kiel University, Germany. At the same time, the total organic carbon (TOC) and $\delta^{13} C_{\text {org }}$ of all the samples were measured at the State Key Laboratory of Lake Science and Environment, Nanjing Institute of Geography and Limnology, Chinese Academy of Science (CAS); and the Xi' an Institute of the Earth Environment, CAS (Chang et al. 2008).

Nine samples of organic matter were chosen for dating. The first step was to check all the samples under a microscope, then $\sim 10 \mathrm{~g}$ were collected for further study. Each sample was extracted with $1 \%$ $\mathrm{HCl}(4 \mathrm{hr})$. Since the acid was neutralized by sample carbonate, $37 \% \mathrm{HCl}$ was added to bring the $\mathrm{pH}$ back below 1 until the $\mathrm{pH}$ was stable. The purpose of these procedures was to ensure the samples were completely free of $\mathrm{CaCO}_{3}$. At the same time, acid residue was collected in an effort to isolate the acid- and water-soluble fractions of the fulvic acid fraction of the sediment organics. The acid residue was then washed with $1 \% \mathrm{NaOH}$ at $60{ }^{\circ} \mathrm{C}$ for $4 \mathrm{hr}$ and then again with $1 \% \mathrm{HCl}$. The humic acid fraction from the alkali extract was precipitated with $\mathrm{HCl}$, washed, and dried. The combustion to $\mathrm{CO}_{2}$ of the organic fractions was performed in a closed quartz tube together with $\mathrm{CuO}$ and silver wool at $900{ }^{\circ} \mathrm{C}$.

Fossil shells from 5 samples were also picked out for dating. These shells were cleaned with $30 \%$ $\mathrm{H}_{2} \mathrm{O}_{2}$ in an ultrasonic bath to remove the organic surface coating and adhering dust as well as detrital carbonate. The $\mathrm{CO}_{2}$ was liberated from the carbonates with $100 \%$ phosphoric acid at $90{ }^{\circ} \mathrm{C}$. The sample $\mathrm{CO}_{2}$ from the combustion and the hydrolysis was then reduced with $\mathrm{H}_{2}$ over $\mathrm{Fe}$ powder as the catalyst, and the resulting carbon/iron mixture was pressed into a pellet in the target holder.

The ${ }^{14} \mathrm{C}$ concentration of the samples was measured by simultaneously comparing the collected ${ }^{14} \mathrm{C}$, ${ }^{13} \mathrm{C}$, and ${ }^{12} \mathrm{C}$ beams of each sample with those of an oxalic acid standard, coal background material (organics), and pre-Eemian foram carbonate (shells), respectively. Conventional ${ }^{14} \mathrm{C}$ ages were calculated according to Stuiver and Polach (1977), with $\delta^{13} \mathrm{C}$ correction for isotopic fractionation based on the ${ }^{13} \mathrm{C} /{ }^{12} \mathrm{C}$ ratio measured by the AMS system simultaneously with the ${ }^{14} \mathrm{C} /{ }^{12} \mathrm{C}$ ratio. Because of fractionation effects during graphitization and inside the spectrometer, this $\delta^{13} \mathrm{C}$ value is usually different from $\delta^{13} \mathrm{C}$ values obtained via an isotopic ratio mass spectrometer (IRMS). 
More detailed information about the sample preparation procedures and ${ }^{14} \mathrm{C}$ background can be found in Schleicher et al. (1998) and Nadeau et al. (1998).

\section{RESULTS AND DISCUSSION}

All AMS dates are listed in Table 1. It is clear that the ages of different materials/components from the same depth are different from one to another.

Table 1 AMS dates on the shell bar section from Qaidam Basin. ${ }^{\text {a }}$

\begin{tabular}{|c|c|c|c|c|c|c|c|c|}
\hline Material/Nr & $\begin{array}{l}\text { Depth } \\
(\mathrm{cm})\end{array}$ & $\begin{array}{l}\text { Lab \# } \\
\text { (KIA-) }\end{array}$ & $\begin{array}{l}\text { Age }(\mathrm{SH}) \\
\text { kyr BP }\end{array}$ & $\mathrm{pMC}$ & $\begin{array}{l}\text { Age (AR) } \\
\text { kyr BP }\end{array}$ & $\mathrm{pMC}$ & $\begin{array}{l}\text { Age (HA) } \\
\text { kyr BP }\end{array}$ & $\mathrm{pMC}$ \\
\hline Shells2 & 35.5 & 29403 & $\begin{array}{l}39.62 \\
+1.65 /-1.4\end{array}$ & $0.72 \pm 0.14$ & & & & \\
\hline TOC2 & 35.5 & 29403 & & & $\begin{array}{l}26.05 \\
+0.23 /-0.22\end{array}$ & $3.91 \pm 0.11$ & $18.25 \pm 0.16$ & $10.31 \pm 0.21$ \\
\hline Shells3 & 53.5 & 29402 & $\begin{array}{l}41.35 \\
+2.11 /-1.67\end{array}$ & $0.58 \pm 0.13$ & & & & \\
\hline TOC3 & 53.5 & 29402 & & & $22.11 \pm 0.19$ & $6.37 \pm 0.15$ & $\begin{array}{l}20.22 \\
+0.36 /-0.35\end{array}$ & $8.07 \pm 0.36$ \\
\hline Shells4 & 92.5 & 29401 & $\begin{array}{l}39.78 \\
+1.69 /-1.4\end{array}$ & $0.71 \pm 0.13$ & & & & \\
\hline TOC-4 & 92.5 & 29410 & & & $\begin{array}{l}18.45 \\
+0.19 /-0.18\end{array}$ & $10.06 \pm 0.23$ & & \\
\hline Shells5 & 124.5 & 23777 & $\begin{array}{l}45.28 \\
+2.62 /-1.97\end{array}$ & $0.36 \pm 0.28$ & & & & \\
\hline TOC5 & 124.5 & 23777 & & & $\begin{array}{l}28.98 \\
+0.51 /-0.48\end{array}$ & $2.71 \pm 0.17$ & $\begin{array}{l}32.18 \\
+1 /-0.89\end{array}$ & $1.82 \pm 0.21$ \\
\hline TOCA & 139 & 29098 & & & $\begin{array}{l}29.42 \\
+0.63 /-0.59\end{array}$ & $2.57 \pm 0.20$ & $\begin{array}{l}31.03 \\
+0.46 /-0.43\end{array}$ & $2.10 \pm 0.12$ \\
\hline TOC7 & 152 & 23776 & & & $\begin{array}{l}30.51 \\
+0.65 /-0.6\end{array}$ & $2.24 \pm 0.17$ & $\begin{array}{l}27.89 \\
+0.38 /-0.36\end{array}$ & $3.10 \pm 0.14$ \\
\hline Shells9 & 187.5 & 29097 & $\begin{array}{l}49.39 \\
+4.89 /-3.02\end{array}$ & $0.21 \pm 0.10$ & & & & \\
\hline TOC9 & 187.5 & 29097 & & & $>43.49$ & $0.09 \pm 0.18$ & $\begin{array}{l}20.92 \\
+0.32 /-0.31\end{array}$ & $7.40 \pm 0.29$ \\
\hline TOC10 & 211 & 29099 & & & $\begin{array}{l}30.29 \\
+0.45 /-0.43\end{array}$ & $2.30 \pm 0.13$ & $\begin{array}{l}22.29 \\
+0.52 /-0.50\end{array}$ & $6.23 \pm 0.25$ \\
\hline TOC11 & 231 & 29100 & & & $>45.28$ & $0.00 \pm 0.18$ & $\begin{array}{l}15.27 \\
+0.57 /-0.53\end{array}$ & $14.93 \pm 0.03$ \\
\hline
\end{tabular}

${ }^{a}$ Note: $\mathrm{SH}=$ fossil shells; $\mathrm{AR}=$ alkali residual; $\mathrm{HA}=$ humic acids.

The results from alkali residues are considered the "sample ages" of the tested materials because this fraction of organic matter has stable sediment patterns. However, these "sample ages" do not necessarily represent the "true ages" of the sedimentation and/or sample formation since the sediments might also be contaminated by inherited old organic matter resulting from reworking/ sedimentation of the materials. In the shell bar section samples, the alkali residues remaining after extraction had very low carbon contents. This is consistent with the low TOC content of the sediments (with an average of $0.12 \%$ and range of $0.05 \sim 0.22 \%$ ). Also, an organic geochemistry biomarker property revealed that the organic matter originated mainly from bacteria-algae (Zhang et al. 2007a). We processed large samples, so that combustion of the alkali residues still gave approximately the recommended $1 \mathrm{mg}$ of carbon, to achieve normal targets and ion beam intensities. For the alkali residues of samples TOC9 (KIA-29097) and TOC11 (KIA-29100), the ${ }^{14} \mathrm{C}$ content is less than twice the measurement uncertainty. In these cases, the age of a sample was calculated with the measured ${ }^{14} \mathrm{C}$ content plus twice the measurement uncertainty, and the real age of the sample is greater than this minimum age with $98 \%$ probability $(2 \sigma)$. 
The results from the soluble organic fractions presented a much more complex picture. Two fulvic acid fractions were isolated and turned out to be almost purely mineral. They did not yield any usable carbon upon combustion. The humic acid fractions also consisted mainly of minerals (carbon content $1.78-0.14 \%$, calculated from $\mathrm{CO}_{2}$ yield). This low carbon content of the humic acid fraction was consistent with the light, yellowish color of the alkali extract. Upon combustion, sample TOC2 (KIA-29403) gave the most carbon ( $0.82 \mathrm{mg}$, calculated from $\mathrm{CO}_{2}$ yield), enough to be measured normally. The other humic acid fractions gave too little carbon to be graphitized normally, and TOC4 (KIA-2940) had no carbon. To obtain a better C:Fe ratio and a larger ion beam, samples TOC9 (KIA-29097), TOC11 (KIA-29100), and TOC3 (KIA-29402) were reduced with $1 \mathrm{mg}$ of iron instead of with the normal 2-mg iron catalyst. As a result, 2 of the samples, KIA-29097 and -29402, produced normal ion beams and $\delta^{13} \mathrm{C}$ isotope ratios. Thus, we consider these results reliable. The other sample, KIA-29100 (0.15 mg C), only gave $44 \%$ of the ion beam intensity of normal 1-mg C samples. It was then normalized to similar-sized OXII standards and thus gave a normal $\delta^{13} \mathrm{C}$ value. Yet, considering its low carbon content and small sample size, the significance of the KIA-29100 result is less reliable.

All the shell samples tested gave approximately $1 \mathrm{mg}$ of carbon, enough for a precise measurement, and all produced sufficient ion beams. Also, the $\delta^{13} \mathrm{C}$ values were in the normal range for freshwater bicarbonate. Thus, the results are considered reliable. The ${ }^{14} \mathrm{C}$ content of the samples was very low $(<0.72 \mathrm{pMC})$ and decreased with increasing depth. The age inversion from sample Shells3 (KIA29402 ) at $53.5 \mathrm{~cm}$ to Shells4 (KIA-29401) at $92.5 \mathrm{~cm}$ was not statistically significant; thus, the carbonate ages form a consistent set. X-ray and scanning electron microscope (SEM) analyses revealed that the fossil shells were composed of pure aragonite. We therefore have confidence that these results represent a good age determination of the samples.

Another factor that needs to be discussed is the carbon reservoir effect; it is a complex problem in ${ }^{14} \mathrm{C}$ dating and there is no satisfactory solution up to now. Results demonstrate that the carbon reservoir effect varies from one lake to another and varies for organic matter of different origins. For example, the carbon reservoir effect of authochtonous algae in Lake Baikal is around $1000 \pm 500 \mathrm{yr}$ (Colman et al. 1996). Our results show that the AMS ages of surface sediments (1-cm-thick colloid matter at the interface between the salt water and sediments) in Zigetang Co., central Tibetan Plateau, was dated at $1270 \pm 20$ and $1078+160 /-157 \mathrm{yr}$ old. However, the organic matter (plant remains in shallow water) from Qarhan salt lake was dated as modern (Table 2). In Sugan Lake,NW Qaidam Basin, the carbon reservoir effect of inorganic carbonate and total organic matter were about 2590 and $2430 \mathrm{yr}$, respectively (Qiang et al. 2005). Nevertheless, based on the available data, we conclude that the modern sediment-which has no exogenous organic matter input and is dominated by local plants - has no carbon reservoir effect. Other modern lake sediments, which are only influenced by the microbes, have a carbon reservoir effect of about 1100-1300 yr. We realize that more work needs to be done before we can fully understand the ${ }^{14} \mathrm{C}$ reservoir effect. In our study, as the environment at present is completely different from that in the geological past, like during the high paleolake level period in Qaidam Basin, we could not use the modern carbon effect of organic matter to estimate the reservoir effect in the past. Here, we use the measured ages to establish the chronology since the carbon reservoir effect of organic matter usually resulted in sample ages 500 to $3500 \mathrm{yr}$ older than the true age of the sample. Thus, the true age of the tested sample could be calculated by the measured result minus the carbon reservoir effect (500-3500 yr), while calibration makes the measured age older by hundreds to thousands of years (Bard et al. 1993; Kitagawa and van der Plicht 1998a,b). This means that the error coming from the calibration is of the same order as that from the reservoir effect. 
Table 2 AMS dates of modern surface samples from salt lake Qarhan, Qaidam Basin, China.

\begin{tabular}{|c|c|c|c|c|c|c|c|}
\hline Material \# & $\begin{array}{l}\text { Lab \# } \\
\text { (KIA-) }\end{array}$ & $\begin{array}{l}\text { Age } \\
\text { (alkali } \\
\text { residue) }\end{array}$ & pMC & $\delta^{13} \mathrm{C}$ & $\begin{array}{l}\text { Age } \\
\text { (humic } \\
\text { acid) }\end{array}$ & $\delta^{13} \mathrm{C}$ & $\mathrm{pMC}$ \\
\hline QDM-2006B-2 & 31400 & $>1950$ & $104.16 \pm 0.25$ & $24.65 \pm 0.35$ & $>1950$ & $27.94 \pm 0.15$ & $103.81 \pm 0.39$ \\
\hline QDM-2006C-3 & 31401 & $>1950$ & $117.96 \pm 0.25$ & $25.93 \pm 0.13$ & & & \\
\hline
\end{tabular}

The age results are given in Figure 2, together with the age-depth relationship, TOC content, and $\delta^{13} \mathrm{C}$ value of the TOC (Chang et al. 2007). It is clear that the dates given by alkali residues and humic acids show different trends. For example, from $124.5 \mathrm{~cm}$ upwards the dates from humic acids were reasonable, but those of alkali residues show a reverse pattern. Moving downward, the humic acid dates show younger ages with increasing depth, while the dates given by alkali residues fluctuate. These phenomena imply that the 2 different organic fractions may have been influenced by 2 separate processes. Possible explanations are the alkali residual fraction most likely had been affected by old/dead carbon-bearing reworked material due to the study section's proximity to the edge of the paleolake. This location could be easily influenced by eroded old deposits; the backward eroded cliffs in the southeast and northeast of the basin clearly show strong eroding processes during the high paleolake level development. Also, 2 springs, the Upper Spring and Big Spring, were found in the western part of the bar. Thus, the humic acid fraction could have been contaminated by underground water because there is no water precipitation from the top of the section downward, as shown by the crystallized salt overlying the section. Upward groundwater movement along with transported soluble organic matter could explain the age reversal. The amount of this soluble organic material should be very small, however, because the strongest age reversal was in the base, where the TOC content remained low-meaning that the change in the soluble organic fraction did not make the TOC content change, nor the $\delta^{13} \mathrm{C}$ value (Figure 2).

Considering all the possibilities, we argue that the age measurements of samples TOC3 (KIA29402 ) at $53.5 \mathrm{~cm}$ depth, TOC5 (KIA-23777) at $124.5 \mathrm{~cm}$, TOCA (KIA-29098) at $139 \mathrm{~cm}$, and TOC7 (KIA-23776) at $152 \mathrm{~cm}$ represent the ages of the material formation. Since the difference between the ages given by alkali residues and humic acids was small, the results were comparable. This assumption is further supported by the conventional ${ }^{14} \mathrm{C}$ dating results (Figure 2A, line 3) obtained at the ${ }^{14} \mathrm{C}$ laboratory in Lanzhou University, China (data after Zhang et al. 2007b). Other dates most likely have been subject to either old/dead carbon influence or strong contamination of the young soluble organic matter and should not be used for establishment of chronology. Such a phenomenon has already been identified by others (Bard et al. 1993; Colman et al. 1996; Geyh et al. 1999; Schramm et al. 2000; Zhang et al. 2006a,b).

It is difficult, maybe impossible, to determine which AMS date is reliable and accurate when the organic matter in the tested samples is too low or the sediments reworked or contaminated. Our study on the shell bar section demonstrated that the following 3 critical references could be used to check the reliability and accuracy of the AMS dates (see Figure 2): 1) the consistency of the dates of both the alkali residual and acid-soluble components of the organic carbon; 2) the total organic carbon (TOC) content; and 3) the stable carbon isotopes $\left(\delta^{13} \mathrm{C}_{\mathrm{org}}\right.$ ). When dates given by the alkali residual and acid-soluble components of the organic carbon are consistent, they are considered reliable and accurate when the TOC content is high enough $(>0.15 \%$, or minimum $>0.05 \%)$ and the $\delta^{13} \mathrm{C}_{\text {org }}$ lower than $-23 \%$, implying that the organic matter originated from terrestrial plants. Certainly, more research is needed to test whether this assumption is also suitable for other cases. 

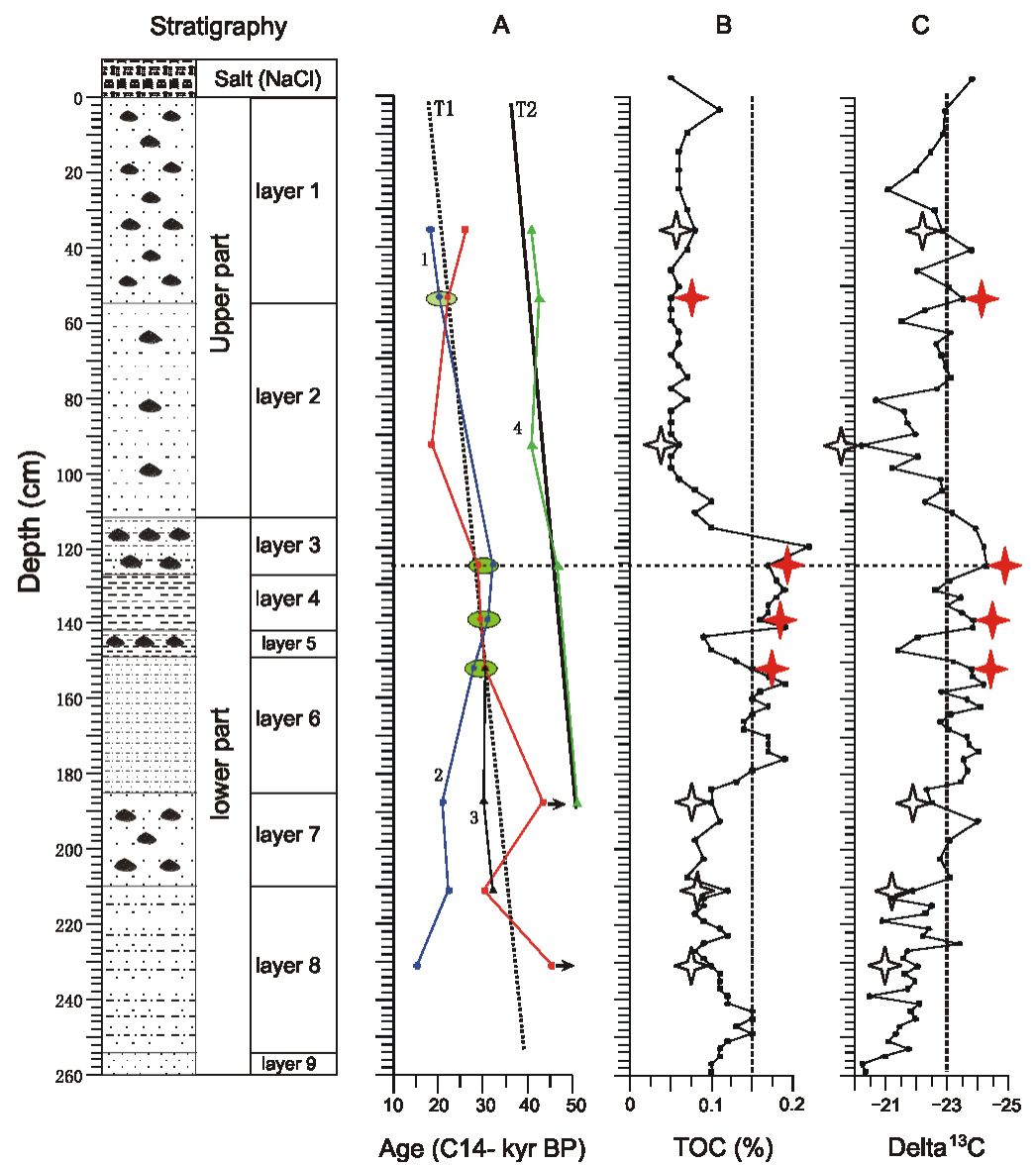

Figure 2 Stratigraphy of shell bar section. A: age-depth distribution patterns; B: TOC content; and $\mathrm{C}$ : $\delta^{13} \mathrm{C}$ depth profiles. For (A), line 1: AMS ages of alkali residues, the arrows indicate the actual ages measured are older than the ages at these points; line 2: AMS ages of humic acids; line 3: conventional ${ }^{14} \mathrm{C}$ ages of TOC (data after Zhang et al. 2007a,b); line 4: AMS ages of fossil shells. The shaded ovals are the AMS ages of organic components believed to represent the "true ages" of tested samples and their regression line (T1), while $\mathrm{T} 2$ is the regression line of the AMS ages of fossil shells. In (B) and (C), solid stars: TOC and $\delta^{13} \mathrm{C}$ values at which "true ages" were obtained; and blank stars: samples that gave false ages.

Using the 4 alkali residue dates discussed above, the regression line T1 can be drawn in Figure 2. When this line is extrapolated both upward and downward, the age at the top of the section is $~ 17.5$ ${ }^{14} \mathrm{C}$ kyr BP, while the bottom of layer 8, considered the initiation of the high paleolake level, is $\sim 39.7$ ${ }^{14} \mathrm{C}$ kyr BP, without considering the reservoir effect.

On the other hand, the fossil shell dates gave the regression line T2 (Figure 2), which is almost parallel to T1 and the difference between them is about 15 18 kyr. Because the AMS ages given by fossil shells are comparable to that by carbonate of bulk sample (data after Zhang et al. 2007b), even though the stable isotopes $\left(\delta^{18} \mathrm{O}\right.$ and $\left.\delta^{13} \mathrm{C}\right)$ between them are strongly divergent (Chang et al. 2007), we have confidence in these results. The difference between T1 and T2 could thus be argued to be due to the addition of "dead carbon" to the fossil shells in Qaidam Basin. As discussed previously, the dead carbon effect of organic matter itself has not been taken into account. This assumption is 
being tested using different methods and if it could be proven true, then it would be the largest old/ dead carbon effect ever detected for the Late Pleistocene.

Halite mineral deposits are widely distributed in the upper part of the Qarhan salt lake deposits. Huang and Cai (1987), Liang and Huang (1995), and Yang et al. (1995) conducted many tests using ${ }^{230}$ Th dating. A detailed examination and correlation of these dates indicates that all the dates by an unbalanced U-series give an age of $\sim 50 \mathrm{kyr}$ BP at the boundary between the salt-rich deposits and the lacustrine clay sediments (Figure 3), which is much older than $24{ }^{14} \mathrm{C}$ kyr BP, as suggested by Zhang (1975), Chen et al. (1987a,b), Huang and Cai (1987), and Liang and Huang (1995).

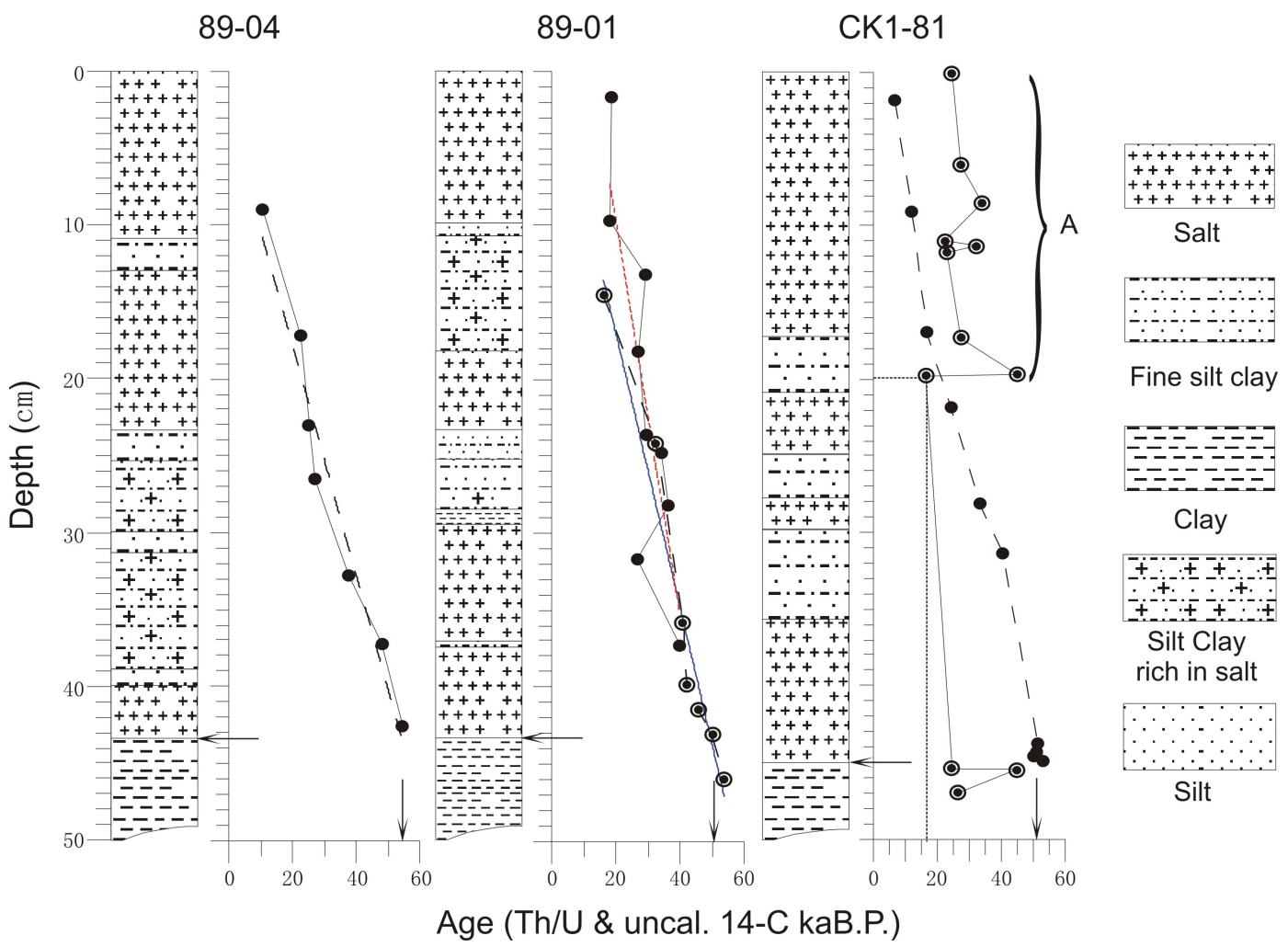

Figure 3 Correlation of cores and their dates in north Dabusun Lake, central paleolake Qarhan. In core 89-04, dotted curve $=\mathrm{U} / \mathrm{Th}$ age-depth relation and dashed line $=$ linear trend. In core 89-01, dotted curve $=\mathrm{U} / \mathrm{Th}$ age-depth relation and dotted line $=$ linear trend; curve with circled dots $={ }^{14} \mathrm{C}$ age-depth relation and the line $=$ linear trend. In core CK1-81, dotdashed curve $=\mathrm{U} / \mathrm{Th}$ age-depth relation and curve with circled dots $={ }^{14} \mathrm{C}$ age-depth relation. The letter "A" marks the ${ }^{14} \mathrm{C}$ age reversals, i.e. ages older than the results given by U/Th dating (all dates are after Huang and Cai 1987; Liang and Huang 1995; Yang et al. 1995).

We applied the sector inductively coupled plasma-mass spectroscopy ${ }^{230} \mathrm{Th}$ dating method (at the University of Minnesota, USA) to date 3 halite crystal samples taken from the salt crust on the top of the shell bar section. The results indicate that the uncorrected ${ }^{230} \mathrm{Th}$ ages of the halite crystal samples are $158.4 \pm 18,158 \pm 15$, and $119.3 \pm 16 \mathrm{kyr}$ BP. These dates are much older than that ${ }^{14} \mathrm{C}$ ages of organic matter from the underlying lacustrine deposits and of the inorganic carbonate and shell fossils. The test results show that the ${ }^{232} \mathrm{Th}$ content is high (up to $3490-22,220 \mathrm{ppt}$ ), and the ${ }^{230} \mathrm{Th} /$ ${ }^{232} \mathrm{Th}$ ratios $\left(2.8 \times 10^{-6}\right.$ to $5.4 \times 10^{-6}$, average of about $\left.4 \times 10^{-6}\right)$ are even less than the assumed initial 
${ }^{230} \mathrm{Th} /{ }^{232} \mathrm{Th}$ value $\left(4.4 \times 10^{-6}\right)$ for calculation, indicating there is a large amount of detrital thorium not originating from ${ }^{238} \mathrm{U}$ decay procedures. Thus, these results may not represent the ages of the halite crystal formed, just as a reasonable age-depth correlation of TL, OSL, and IRSL dates of the core D100 in Ejina Basin does not represent the true age of the sediments (Zhang et al. 2006b). Furthermore, as previous studies (Huang and Cai 1987; Liang and Huang 1995; Yang et al. 1995) did not give information as to what kind of material was used for dating, it is difficult to evaluate the reliability of these ${ }^{14} \mathrm{C}$ dates. If the dates were of inorganic carbon, then, as our results show, the dates of shells and inorganic carbon are much older than that of organic matter. Due to the U/Th dating requirements and open nature of the system, these results cannot be used to confirm or disregard the ${ }^{14} \mathrm{C}$ dating results. We believe that U/Th dating results are unreliable, and thus this technique is unsuitable to date the Qaidam Basin samples.

\section{CONCLUSIONS}

Study of the shell bar section in Qaidam Basin, NE Tibetan Plateau, showed that it was formed between $\sim 39.7$ and $\sim 17.5{ }^{14} \mathrm{C}$ kyr BP. Even though there are problems and uncertainties that are common in paleolake deposit studies, this paper shows the most comprehensive age test and determination in the area and provided an important and useful chronological scale for future research. In using AMS ${ }^{14} \mathrm{C}$ dating, it is helpful to measure the ages of both alkali residues and humic acids to ensure the reliability and accuracy of the dates. This is because sediments might not only be influenced by reworked old materials, but might also be contaminated by the young soluble organic fraction. Such sediments are common in arid areas since both drastic climatic changes in the past and neutectonic activities may have strongly influenced the transportation and sedimentation processes in these and similar areas (Zhang et al. 2006b). Certainly, AMS ages of humic acids cannot ensure the accuracy of the alkali residue AMS ages, but at least they can provide information about whether the tested sample had been influenced by younger/older mobile matter.

Based on the above discussion, we conclude that the shell bar section represents the high paleolake level, formed between $\sim 39.7$ and $\sim 17.5{ }^{14} \mathrm{C}$ kyr BP. Even if there are still unresolved problems, this research is the most systematic and comprehensive study of the shell bar section in Qaidam Basin and provides a useful reference for the study of environmental evolution during the Late Pleistocene in the area. It reveals geological facts that indicate the existence of a huge uniform paleolake in the area, which is an indication of the readjustments and changes in the regional climate. This conclusion is consistent with study results in other arid areas in NW China (Peng et al. 1998; Zhang et al. 2001, 2002, 2004) and supports the Thompson et al. (1997) Guliya ice-core study results in the western Tibetan Plateau. The fossil shells preserved in the sediments indicate a mild, warm climate suitable for Corbicula. The dates given by inorganic carbonate and fossil shells are comparable, indicating that they shared common ${ }^{14} \mathrm{C}$ sources. However, for reasons still unknown, there is a difference of 15-18 kyr between the age of the inorganic carbonate (including fossil shells) and the organic matter. Our study also proved that the U/Th dating method may not be suitable to date halite crystal samples from Qaidam Basin.

\section{ACKNOWLEDGMENTS}

This study was supported by the Hundred Talent Project of the Chinese Academy of Sciences and NSFC (40371117 \& 40721061). Special thanks to Prof. Dr. P Grootes for discussions of the AMS results and to the anonymous reviewers for constructive comments that improved the manuscript greatly. 


\section{REFERENCES}

Bard E, Arnold M, Fairbanks RG, Hamelin B. 1993. ${ }^{230} \mathrm{Th}-{ }^{234} \mathrm{U}$ and ${ }^{14} \mathrm{C}$ ages obtained by mass spectrometry on corals. Radiocarbon 35(1):191-9.

Bowler JM, Huang Q, Chen K, Head MJ, Yuan B. 1986. Radiocarbon dating of playa-lake hydrologic changes: examples from northwestern China and central Australia. Palaeogeography, Palaeoclimatology, Palaeoecology 54(1-4):241-60.

Chang FQ, Zhang HC, Chen Y, Yang MS, Zhang WX, Lei GL, Fan HF. 2007. Stable isotopes of carbonate and fossil shells from the shell bar section of the paleolake Qarhan, Qaidam Basin. Quaternary Sciences 27(3):427-36. In Chinese.

Chang FQ, Zhang HC, Chen Y, Yang MS, Niu J, Fan HF, Lei GL, Zhang WX, Lei YB, Yang LQ. 2008. Sedimentation geochemistry and environmental changes during the Late Pleistocene of paleolake Qarhan in the Qaidam Basin. Journal of China University of Geosciences $19(1): 1-8$.

Chen KZ, Bowler JM. 1985. The feature of Chaerhan salt lake deposit in Qaidam Basin and palaeoclimatology evolution. Science in China B 5:464-72.

Chen KZ, Bowler JM. 1986. Late Pleistocene evolution of salt lakes in the Qaidam Basin, Qinghai Province, China. Palaeogeography, Palaeoclimatology, Palaeoecology 54(1-4):87-104.

Chen KZ, Tang Y, Li B, Xu C, Huang Q, Gao Z, Bowler JM. 1987a. Evolution of salt lakes in the Late Pleistocene in Qaidam Basin, Qinghai Province. In: Geological Evolution in the Qaidam Basin, Qinghai, from the Late Pleistocene. Beijing: Science Press. p 34-46. In Chinese.

Chen KZ, Yuan BY, An ZS. 1987b. Paleoenvironment of arid and semi-arid regions in China and Australia since 50,000 years. In: Collected Papers from the Quaternary Sciences Conference. Beijing: Science Press. p 66-82. In Chinese.

Colman SM, Jones GA, Rubin M, King JW, Peck JA, Orem WH. 1996. AMS radiocarbon analyses from Lake Baikal, Siberia: challenges of dating sediments from a large, oligotrophic lake. Quaternary Science Reviews 15(7):669-84.

Derbyshire E, Shaw J, Wang JT. 1985. Palaeomagnetic age of the borehole No.1 of Dabusun Lake, Qaidam Basin. Journal of Glaciology and Geocryology (China) 7(3):229-32.

Geyh MA, Grosjean M, Nuñez L, Schotterer U. 1999. Radiocarbon reservoir effect and the timing of the Late-Glacial/Early Holocene humid phase in the Atacama Desert (northern Chile). Quaternary Research 52:143-53.

Huang Q, Cai PQ. 1987. Geochronological study on the sediments in Qarhan Lake. In: Collected Papers from the Quaternary Sciences Conference. Beijing: Science Press. p 106-14. In Chinese.

Huang Q, Meng ZQ, Liu HL. 1995. The study of palae- oclimatology fluctuation pattern in Chaerhan Lake, Qaidam Basin. Science in China B 15:652-63.

Huang WW, Chen KZ, Yuan BY. 1987. Discovery of paleolithic artifacts in the Xiao Qaidam lake area, Qinghai Province. In: Collected Papers from the Quaternary Sciences Conference. Beijing: Science Press. p 168-75. In Chinese.

Jiang DX, Yang HQ. 2001. Palynological evidence for climatic changes in Dabusun Lake of Qinghai Province during the past 500,000 years. Acta Sedimentologica Sinica 19(1):101-9. In Chinese.

Kitagawa H, van der Plicht J. 1998a. A 40,000-year varve chronology from Lake Suigetsu, Japan: extension of the ${ }^{14} \mathrm{C}$ calibration curve. Radiocarbon 40(1):505-15.

Kitagawa H, van der Plicht J. 1998b. Atmospheric radiocarbon calibration to 45,000 yr B.P.: late Glacial fluctuations and cosmogenic isotope production. Science 279(5354):1187-90.

Liang QS, Huang Q. 1995. Salt-forming ages of the Dabusun and Bieletan regions in Qarhan playa, Qinghai. Acta Sedimentologica Sinica 13(3):126-31. In Chinese.

Liu ZC, Wang YJ, Chen Y, Li XS, Li QC. 1998. Magnetostratigraphy and sedimentologically derived geochronology of the Quaternary lacustrine deposits of a $3000 \mathrm{~m}$ thick sequence in the central Qaidam Basin, western China. Palaeogeography, Palaeoclimatology, Palaeoecology 140(1-4):459-73.

Nadeau M-J, Grootes PM, Schleicher M, Hasselberg P, Rieck A, Bitterling M. 1998. Sample throughput and data quality at the Leibniz-Labor AMS facility. Radiocarbon 40(1):239-45.

Peng JL, Zhang HC, Ma YZ. 1998. Late Pleistocene limnic ostracods and their environmental significance in the Tengger Desert, northwestern China. Acta Micropalaeontologica Sinica 15(1):22-30. In Chinese.

Qiang M, Chen F, Zhang J, Gao S, Zhou A. 2005. Climatic changes documented by stable isotopes of sedimentary carbonate in Lake Sugan, northeastern Tibetan Plateau of China, since 2 ka BP. Chinese Science Bulletin 50(17):1930-9.

Schleicher M, Grootes PM, Nadeau M-J, Schoon A. 1998. The carbonate ${ }^{14} \mathrm{C}$ background and its components at the Leibniz AMS facility. Radiocarbon 40(1): 85-93.

Schramm A, Stein M, Goldstein SL. 2000. Calibration of the ${ }^{14} \mathrm{C}$ time scale to $>40 \mathrm{ka}$ by ${ }^{234} \mathrm{U}-230 \mathrm{Th}$ dating of Lake Lisan sediments (last glacial Dead Sea). Earth and Planetary Science Letters 175(1-2):27-40.

Stuiver M, Polach HA. 1977. Discussion: reporting of ${ }^{14} \mathrm{C}$ data. Radiocarbon 19(3):355-63.

Sun DP. 1974. Origin of recent potash deposits in a certain salt lake, China. Chinese Journal of Geochemistry 4(3):230-48.

Sun DP. 1990. Origin of potash deposits in the Qaidam 
Basin, China. Science in China B 33(2):198-210.

Thompson LG, Yao T, Davis ME, Henderson KA, Mosley-Thompson E, Lin P-N, Beer J, Synal H-A, ColeDai J, Bolzan JF. 1997. Tropical climate instability: the last glacial cycle from a Qinghai-Tibetan ice core. Science 276(5320):1821-5.

Wang JT, Derbyshire E, Shaw J. 1986. Preliminary magnetostratigraphy of Dabusun Lake, Qaidam Basin, central Asia. Physics of the Earth and Planetary Interiors 44(1):41-6.

Yang W, Spencer RJ, Krouse HR, Lowenstein TK, Casas E. 1995. Stable isotopes of lake and fluid inclusion brines, Dabusun lake, Qaidam Basin, western China: hydrology and paleoclimatology in arid environments. Palaeogeography, Palaeoclimatology, Palaeoecology 117(3-4):279-90.

Yang XP. 2002. Water chemistry of the lakes in the Badain Jaran Desert and their Holocene evolution. Quaternary Sciences 22(2):97-104.

Zhang BZ. 1975. Time range of the great ice age of the last glacial stage and its related geological event of playa in the Qinghai-Xizang (Tibet) Plateau. Quaternary Sciences 3:193-201. In Chinese.

Zhang HC, Ma YZ, Li JJ, Qi Y, Chen GJ, Fang HB, Wünnemann B, Pachur H-J. 2001. Palaeolake evolution and abrupt climate changes during last glacial period in NW China. Geophysical Research Letters 28(16): 3203-6.

Zhang HC, Wünnemann B, Ma YZ, Peng J, Pachur H-J, Li J, Qi Y, Chen G, Fang H, Fenge Z. 2002. Lake level and climate change between 42,000 and $18,000{ }^{14} \mathrm{C}$ yr
B.P. in the Tengger Desert, NW China. Quaternary Research 58(1):62-72.

Zhang HC, Peng JL, Ma YZ, Chen GJ, Feng Z-D, Li B, Fan HF, Chang FQ, Lei GL, Wünnemann B. 2004. Late Quaternary palaeolake levels in Tengger Desert, NW China. Palaeogeography, Palaeoclimatology, Palaeoecology 211(1):45-58.

Zhang HC, Li B, Yang MS, Lei GL, Ding H, Niu J, Fan HF, Zhang WX, Chang FQ. 2006a. Dating paleosol and animal remains in loess deposits. Radiocarbon 48(1):109-16.

Zhang HC, Ming QZ, Lei GL, Zhang WX, Fan HF, Chang FQ, Wünnemann B, Hartman K. 2006b. Dilemma of dating on lacustrine deposits in a hyperarid inland basin of NW China. Radiocarbon 48(2):21926.

Zhang HC, Chang FQ, Li B, Lei GL, Chen Y, Zhang WX, Niu J, Fan HF, Yang MS. 2007a. Branched aliphatic alkanes of shell bar section in Qarhan Lake, Qaidam Basin and their paleoclimate significance. Chinese Science Bulletin 52(9):1248-56.

Zhang HC, Lei GL, Chang FQ, Fan HF, Yang MS, Zhang WX. 2007b. Age determination of the shell bar section in salt lake Qarhan, Qaidam Basin. Quaternary Sciences 27(4):511-21. In Chinese.

Zhang PX. 1988. Salt Lakes in the Qaidam Basin. Beijing: Science Press. In Chinese.

Zhang PX, Zhang BZ. 1991. Preliminary study on paleoclimate and paleoenvironment of the Qaidam region since three million years ago. Acta Geographica Sinica 46(3):327-35. In Chinese. 